$\stackrel{\circ}{I I I}$

\title{
PO MOCHLOS - PROLEGOMENA DO MOŻLIWYCH JESZCZE ROZWAŻAŃ O KONDYCJI UNIWERSYTETU
}

\begin{abstract}
Marek Chojnacki, Magdalena Żardecka, Po mochlos - prolegomena do możliwych jeszcze rozważań o kondycji uniwersytetu [After mochlos - prolegomena to any still possible considerations about the condition of univerisity] edited by M. Obrębska, G. Dziamski „,"Człowiek i Społeczeństwo" vol. XLIX: Humanistyka jutra [Humanities of Tomorrow], Poznań 2020, pp. 87-109, Adam Mickiewicz University. ISSN 0239-3271.
\end{abstract}

The text tackles the problem of the condition of university, in a world blindly believing that the only possible worth measure is economic in nature and, in the name of this belief, setting in motion a ruthless bureaucratic machinery that throttles all kinds of creativity and nips in the bud all nonstandard actions and creations. The world apparently is "out of joint", and things are taking an unexpected turn. University is one of the victims, but also one of active accomplices of this despicable situation. How to speak about the university to those who are exclusively in business of calculating balance of profits and losses? How to speak about it after deconstruction, when all great ideas have been already repeatedly and manifoldly dismounted and discredited? How to speak about it, when the university's men and women have discredited themselves repeatedly as well, oscillating between libido sciendi and libido dominandi? Trying to solve this puzzle, we are following in the footsteps of Derrida, who in his texts about university makes appeal to Kant, and inspired by his invention, we set in motion two opposite traditions, represented by Lyotard, Bourdieu, Bauman and Readings on the one hand, and by Humboldt, Schleiermacher and Jaspers on the other. With Derrida, we make noises about the return of the ideas of truth, of the light of reason, of the autonomy of university. It is, however, a return of the specters of the past, in alignment with Derrida's hauntology. Humanists are people of academia who see these specters, but at the same time are already specters themselves - even if they still show up here and there, they are almost insignificant. They are only allowed to contemplate their negligibility and to confess their habitual helplessness. University always had to defend itself, and it does defend itself today.

Marek Chojnacki, mchojnacki@go2.pl

Magdalena Żardecka, Uniwersytet Rzeszowski, Instytut Socjologii, Zakład Antropologii Kulturowej, ul. Rejtana 16C, 35-959 Rzeszów, magda.zardecka@gmail.com, ORCID: https:// orcid. org/0000-0003-3581-6424. 


\section{Kilka słów o tym, że niewiele można powiedzieć}

W 1980 roku, wygłaszając na Uniwersytecie Columbia w Nowym Jorku mowę z okazji otrzymania doktoratu honoris causa, co zbiegło się ze stuleciem istniejącej tam graduate school, Jacques Derrida sięgnął po klasyczny tekst Immanuela Kanta Spór fakultetów (Kant, 2003, 2018a, 2018b) i, odnosząc się do niego, zdekonstruował granicę pomiędzy władzą i wiedzą (1984), po czym wyznał - nie bez zakłopotania i w poczuciu dużej bezradności - że nie da się nacisku władzy na uniwersytet wyeliminować, nie da się wyprowadzić go na zewnątrz, poza granice uniwersytetu, gdyż nacisk ten wpisany jest w samo dążenie do poznania. W obliczu tego nierozerwalnego splotu władzy i wiedzy nowożytna idea autonomii uniwersytetu, która w obszarze języka niemieckiego ukształtowała się w latach 1798 (Spór fakultetów Kanta) - 1810 (założenie uniwersytetu w Berlinie), rozwiewa się jak dym. Pomimo to Derrida chce zachować misję czy też profesję profesora („Grammaticum se professus, powiada Cyceron w Rozmowach tuskulańskich" - Derrida, 2015: 45), czyniąc z owego wyznania bezradności tej profesji paradoksalny wyróżnik.

Dwadzieścia lat później Derrida powrócił do tych kwestii w tekście Uniwersytet bezwarunkowy (L'Université sans condition, 2001; w polskim tłumaczeniu tekst ten ukazał się w roku 2015). Podtrzymuje w nim przekonanie o ważności roszczenia uniwersytetu do „bezwarunkowej wolności zapytywania i przedkładania propozycji, a nawet prawa publicznego głoszenia tego wszystkiego, czego wymagają badania, wiedza i myślenie prawdy" (Derrida, 2015: 12). Przyznaje też, że magiczne słowo prawda, wielokrotnie oskarżone i skazane przed trybunałem historii za „zbrodnie przeciwko ludzkości” (s. 15), wciąż się ostaje i nie potrafimy się bez niego obejść:

Bez względu na to, jak enigmatyczne byłoby to odniesienie do prawdy, wydaje się ono na tyle fundamentalne, że powinno się znaleźć, wraz ze światłem (Lux), na większości symbolicznych insygniów uniwersytetu. Uniwersytet czyni z prawdy wyznanie. Deklaruje, obiecując zarazem, bezgraniczne zobowiązanie wobec prawdy. (s. 12)

Słowa te w ustach proroka dekonstrukcji brzmią bardzo mocno - prawda i dążenie do niej pozostają niezbywalnym wymiarem wolnego wyznania wiary (owego credo, nie crede, jak mówi Kant - Kant, 2018a: 38), bez którego nie ma profesji profesora. Ale wciskający się w działalność uniwersytecką 
nierozerwalny splot libido sciendi i libido dominandi, splot wymiaru konstatywnego i performatywnego, musi sprawić, że owa szlachetna troska o lux veritatis przyprawia nas dziś o potężny ból głowy. Z braku innej możliwości przyjdzie nam chyba zamienić się w teologów uprawiających refleksję apofatyczną po to, by niestrudzenie jak oni zaprzeczać, że nie możemy mówić tego, co jesteśmy zobowiązani mówić, i nie możemy dążyć do tego, do czego jesteśmy zobowiązani dążyć.

W rozważaniach z 2001 roku Derrida odsyła nas do nowojorskiej mowy o mochlos z roku 1980, która z kolei odsyła nas do roku 1798, kiedy to Kant pisał swój Spór fakultetów. Przyjrzyjmy się zatem temu, co Kant mówił w swoim dziele. Granice między światem wiedzy a światem władzy są, jego zdaniem, dość wyraźnie zaznaczone i odzwierciedlone w strukturze uniwersytetu - trzem zależnym od władzy fakultetom „wyższym” (teologii, prawa i medycyny), „których nauki, jakie one są, i czy mogą być publicznie nauczane, rząd sam interesują”, przeciwstawiony jest jeden niższy - reprezentowany przez filozofię - który „się tylko trudni interesem umiejętności” i dlatego „może mieć twierdzenia takie, jakie jemu się podobają” (Kant, 2018a: 37). Komfort filozofów polega więc na tym, że jako jedyni tworzą grupę uczonych wolnych od wszelkich nacisków władzy i kierujących się wyłącznie „interesem umiejętności”, dzięki czemu światło prawdy może ich swobodnie oświecać. Wydziałowi filozoficznemu (tak, jak rozumie go Kant) przypada najwyższa posługa - służenie samej tylko prawdzie.

Wynika z niej dodatkowa funkcja - prawo do sprawowania kontroli nad wszystkimi fakultetami „wyższymi”, które pozostają zawsze zależne od władzy: „Względem trzech wyższych służy on do tego, aby je obrachowywać i przez toż samo mu użytecznym stać się, ponieważ przed wszystkim najpierwej o prawdę (istotny i pierwszy warunek uczoności ogólnie) idzie; użyteczność zaś, której wydziały wyższe na pomoc rządowi obiecują, jest tylko sprawą drugiego rzędu” (Kant, 2018a: 39). Zatem to na filozofii opiera się autonomia uniwersytetu, który dzięki niej ma „własne sądownictwo” (Kant, 2018a: 36).

Któż nie chciałby cieszyć się tak wielką wolnością i zarazem sprawować tak wielkiej władzy, wynikającej z braku podległości władzy jakiejkolwiek? Jedyne, czego mogą obawiać się tak wolni, autonomiczni i podlegający tylko własnemu osądowi uczeni - a nie jest to obawa bezpodstawna to wpływ tych, których Kant nazywa ludźmi interesu albo rzemieślnikami uczoności (Geschäftsleute oder Werkkundige der Gelehrsamkeit). Należą do nich duchowni, juryści i lekarze, kształceni przez trzy „wyższe” fakultety, a następnie powoływani przez państwo do wykonywania swoich zawodów 
i sprawowania różnych funkcji niepozostających bez wpływu na życie uniwersytetu. Derrida (1984), uwspółcześniając nieco nazewnictwo Kanta, grupę ową nazywa biznesmenami i technikami nauki (hommes d'affaires ou techniciens de la science). Ludzie ci, będąc przedstawicielami państwa, funkcjonują „na zewnątrz, na obrzeżach i wewnątrz uniwersytetów” i wywierają nań stały i znaczny wpływ, stanowiąc „niebezpieczną władzę” (pouvoir redoutable). Są oni „niezupełnie związani z nauką i niekoniecznie dobrze wykształceni”, ale bardzo groźni, gdyż mają bezpośredni kontakt z ludem, który, jak mówił brutalnie Kant, składa się w przeważającej części z idiotów (Idioten).

Osobliwością rozważań Kanta było to, że pośród rzemieślników uczoności umieścił on grupę zwaną literatami. Literaci (die Litteraten, Studierte) „mogli się wprawdzie na uniwersytecie uczyć, ale też i mogli wiele zapomnieć z tego, co się nauczyli” (Kant, 2018a: 37). Podobnie jak rzemieślnicy uczoności, nie są oni uczonymi we właściwym sensie tego słowa (eigentliche Gelehrte), lecz są narzędziami rządu, ludźmi związanymi z władzą (Instrumente der Regierung). Im również państwo powierza rozmaite urzędy dla własnych celów, niekoniecznie zaś w najlepszym interesie nauki. Kant spodziewa się jednak, że ich działalność będzie utrzymywana we właściwych granicach, by nie naruszali autonomii uniwersytetu.

Wydaje się, że dziś wyraźniej niż w czasach Kanta rysuje się różnica między rzemieślnikami uczoności a literatami. Współcześni literaci nie przypominają w niczym techników nauki, lecz podobni są do publicystów, których romantyczny obraz nakreśliła w latach 50. XX wieku Simone de Beauvoir. Źródłem autorytetu publicystów jest to, że publikują swoje prace w prestiżowych wydawnictwach (we Francji było to Gallimard). O tym, że mogą oni oddziałać na uniwersytet z wielką siłą, świadczy historia przedstawiona przez Pierre’a Bourdieu w pracy Homo academicus (Simone de Beauvoir, 1954; Bourdieu 1984, 1988). We francuskim systemie szkolnictwa wyższego przed rokiem 1968 funkcjonowały dwie grupy. Jedną z nich Bourdieu określił mianem kasty mandarynów, a drugą - publicystów. Mandaryni mieli pozycję dominującą z tej racji, że ukończyli École normale supérieure lub w niej wykładali bądź uzyskali tak zwaną agregację, czyli coś w rodzaju lepszej habilitacji. Publicyści ukończyli „gorsze” szkoły i zajmowali niższe stanowiska, lecz nie widzieli żadnych powodów, dla których mieliby do końca życia pozostawać sługami „kasty mandarynów”, zakwestionowali więc stary porządek, przeprowadzili rewolucję i obalili absolutną władzę normaliens i agregés.

Już sam fakt rozmywania się pola semantycznego i niewyraźności granic pomiędzy rzemieślnikami uczoności (w rozumieniu Kanta, czyli technikami 
nauki w rozumieniu Derridy) i literatami (w sensie, w jakim mówimy o romantycznym etosie intelektualistów), świadczy o tym, że nie bardzo wiemy, gdzie jesteśmy. Kto jest kim na uniwersytecie i za co ponosi odpowiedzialność? Czym jest władza zagrażająca autonomii uniwersytetu? Z której strony nadciąga zagrożenie? Gdzie przebiegają granice pomiędzy politycznym naciskiem a dociekaniem prawdy? Jak rozumieć niezależność badań naukowych? Jeśli można by zaliczyć francuskich intelektualistów do literatów w rozumieniu Kanta, to pytanie brzmi: czym była przeprowadzona przez nich pod koniec lat 60. XX wieku rewolta na uniwersytetach; czy literaci dokonali zamachu na prawdę i uniwersytet w imię swych partykularnych interesów i podejrzanej ideologii, czy też raczej okazali się wiernymi uczniami prawdy przejętymi odpowiedzialnością za rozum, w imię którego rozbili strukturę wynoszącą na piedestały kastę bezideowych, egoistycznych mandarynów?

W świetle doświadczeń XX wieku skostnienie mandarynów, opisane w Homo academicus Pierre'a Bourdieu, jawi nam się jako pewien wariant Zdrady klerków Juliena Bendy (1927). Klerkowie to uczeni, „których działania nie podążają za praktycznym celem i którzy znajdują przyjemność w uprawianiu sztuk, nauk albo też spekulacji metafizycznych, jednym słowem w posiadaniu dóbr innych niż doczesne” (Benda, 1927, 2014; Lwoff, 2014: 8-9). Wypełniali swoją misję, gdy służyli wyłącznie sprawiedliwości, prawdzie i rozumowi, czyli wartościom znajdującym się „poza rzeczywistością", w każdym razie poza rzeczywistością wąsko rozumianych interesów politycznych, ale gdy porzucili te dążenia i zaangażowali się w stronniczą walkę narodową, społeczną i polityczną - dopuścili się zdrady. Stali się wówczas kantowskimi literatami, narzędziami władzy. Ostateczny wyraz tej zdrady znajdujemy w tyleż przerażającym, co niezrozumiałym pomniku najbardziej radykalnego splątania dążenia do prawdy z fascynacją brutalną władzą i dominacją - w mowie rektorskiej Heideggera z 27 maja 1933 roku, w której pochwała autonomii uniwersytetu przeradza się w celebrację narodowej ,autoafirmacji” (Heidegger, 1983).

Pozornie prosty podział na dwa typy akademików: upadłych klerków, którzy, zamiast bronić nieziemskich wartości prawdy i rozumu, zaangażowali się w partykularną walkę polityczną (nacjonalizm, rasizm, komunizm), i skostniałych mandarynów, którzy zdradzili te same wartości nie tyle przez unurzanie się w politycznej walce, co przez skoncentrowanie się na obronie własnych przywilejów kastowych, szybko jednak zaczyna się rozmywać i komplikować. W przypadku klerków Bendy problem stanowi definicja „partykularności” interesów. Klerk ma prawo zejść z parnasu nieziemskich wartości po to, by sprowadzić nieco światła w doczesność; ma prawo zaangażować się w walkę 
polityczną, byle by tylko trzymał się ,zasady abstrakcyjnej, wyższej i bezpośrednio przeciwstawiającej się emocjom politycznym” (Winock, 1984: 4). Benda miał tu na myśli takie przypadki, jak zaangażowanie się w obronę Alfreda Dreyfusa, które na przełomie wieków XIX i XX stało się miernikiem przyzwoitości intelektualisty. Ale problem nie jest prosty, ponieważ „nie wszystkie spory historyczne prezentują się tak schematycznie, jak sprawa Dreyfusa: z jednej strony niewinny, z drugiej reputacja sztabu armii” - jak zauważa Raymond Aron (1983: 47; por. Winock, 1984: 5).

Podział na to, co uniwersalne i partykularne, nie jest oczywisty. Akademikom niejednokrotnie może się zdawać, że bronią uniwersalnych pryncypiów, angażując się w nader partykularne stanowiska w różnych sporach, a nad obroną prawdy, skoro tylko zstępuje ona w świat doczesności, unosi się zawsze widmo ideologii. Podobnie i Heidegger - jakkolwiek by to dziś nie brzmiało - mógł być przekonany, że broni prawdy, głosząc pochwałę samoafirmacji ludu niemieckiego w pracy uniwersytetu. Wobec faktycznego splątania episteme i doksa, zagadnień teoretycznych i wyzwań praktycznych, przychodzi przyznać, że nie ma ucieczki przed niejednoznacznością. Z pewnego punktu widzenia patrząc, kasta mandarynów, broniąca swych interesów, wypada nieoczekiwanie pozytywne. Można to wyczytać z rozprawy Bourdieu o homo academicus, która skądinąd pisana była z zamiarem zdyskredytowania mandarynów i ukazania pozytywnej strony przemian na francuskim uniwersytecie po roku 1968 (autorzy nieraz bywają zaskoczeni wymową dzieła, które stworzyli).

Czy wobec tej nieusuwalnej niejednoznaczności profesorowie, którzy jak chce Derrida - „czynią z prawdy wyznanie”, mogą wierzyć samym sobie? Dokąd prowadzi wiara w prawdę, niezależność badań i autonomię uniwersytetu? Czy wolno nam dziś jeszcze o nich mówić, a jeżeli tak, to jakim językiem?

Kantowi sen z powiek spędzali nie tylko literaci i rzemieślnicy uczoności, pozostający w służbie władzy, lecz także, a może przede wszystkim, sama władza, zdarzało się bowiem, że przywoływała go ona do porządku, demonstrując swoją siłę i grożąc jej użyciem. Tym, którzy tęsknią do bezpiecznej opieki władcy - pisze Derrida w Mochlos - polecam lekturę słów, niewyobrażalnych dziś w ustach Cartera, Breżniewa, Giscarda d'Estaing czy Pinocheta, a których z trudem można by się spodziewać po ajatollahu (Derrida, 1984). W przedmowie do Sporu fakultetów Kant cytuje list, który otrzymał od króla Prus Fryderyka Wilhelma. W liście tym król stwierdza, iż publikując rozprawę Religia w obrębie samego rozumu, Kant zachował się w sposób niewybaczalnie nieodpowiedzialny: 
Sam musi pan uznać jak nieodpowiedzialnie zachował się pan, działając wbrew swym obowiązkom nauczyciela młodzieży i wbrew naszej monarszej woli, która jest panu doskonale znana. Domagamy się, by jak najrzetelniej wziął pan na siebie odpowiedzialność za swoje czyny i oczekujemy, pod groźbą największej naszej niełaski, że w przyszłości nie popadnie pan w podobne błędy, mając nadzieję, że zgodnie ze swym obowiązkiem użyje pan swej sławy i talentów, by jak najsumienniej pełnić naszą monarszą wolę; w przeciwnym wypadku, jeśli będzie pan trwał w swym uporze i nieposłuszeństwie, może się pan niechybnie spodziewać nieprzyjemnych konsekwencji. (Derrida, 1984; Kant, 1917: 6)

Sytuacja ta - ironizuje Derrida - może dziś budzić nostalgię: przynajmniej było wówczas wiadomo, kto, od kogo i czego wymaga i kto za co ponosi odpowiedzialność. „Przywoływane instancje - państwo, suweren, lud, nauka, działanie, prawda, uniwersytet - miały swoje określone miejsce, rozstrzygalne i we wszelkich znaczeniach tego słowa reprezentowalne w dyskursie; jeden wspólny kod językowy mógł - a przynajmniej tak sądzono - zapewnić minimalną przekładalność wszystkich dyskursów możliwych w tym kontekście” (Derrida, 1984).

Sztuczność wydzielenia (fakultetu) filozofii jako dyscypliny wolnej od gier politycznych i uwarunkowań praktycznych została dostrzeżona już w czasach Kanta. W roku 1802 (czyli w połowie drogi pomiędzy Sporem fakultetów a założeniem uniwersytetu w Berlinie) Friedrich Schelling zauważył, że dla „filozofii” pojmowanej jako postulowana przez Kanta cudowna zdolność wyodrębniania czystego dążenia do prawdy, odgraniczania jej od władzy i dokonywania syntezy wiedzy ludzkiej, nie da się wskazać jakiegoś konkretnego fakultetu (a zatem i konkretnej władzy czy dyspozycji umysłu, faculté): „to, co jest wszystkim, nie może, z tegoż właśnie powodu, być czymś poszczególnym” („ce qui est tout ne peut, pour cette raison précise, être rien de particulier” - Derrida, 1984; „,[Philosophie] begriffe Alles wirklich als Eines, aber sie begriffe eben deswegen Nichts als Bestimmtes" - Schelling, 2016: 59). Skoro nie ma gruntu, na którym można by rozgraniczyć i oddzielić od siebie czyste dążenie do wiedzy i interesowne dążenie do korzyści, poznawanie prawdy i ustanawianie dominacji, teorię i praktykę, akty konstatywne i performatywne, to możliwość wskazania na jedną, stałą grę z jasno określonymi regułami nie istnieje. Konflikty pomiędzy fakultetami uniwersytetu czy rozmaitymi władzami nie dadzą się rozwiązać raz na zawsze w drodze klarownej demarkacji. „Całość” - którą chcielibyśmy nazwać filozofią i użyć jako złotego wytrycha uwalniającego nas z pułapki - „tworzy zapętlone wgłębienie (la poche invaginée) wewnątrz każdej części czy podzbioru” (Derrida, 1984). Z tej pułapki można tylko wychodzić, lecz nie można z niej wyjść. 
Nie wiadomo, czy realna sytuacja jakiegokolwiek uniwersytetu usprawiedliwiała tę wielką idealizację, jaką jest idea autonomii, czy niezależność od władzy i interesów innych niż czysto poznawcze kiedykolwiek istniała, ale na pewno nie istnieje ona dziś. By wytrwać w swojej uniwersyteckiej misji i zachować postulowaną przez Kanta autonomię, musimy nieustannie dokonywać intelektualnego wysiłku, podobnego do fizycznego wysiłku gimnastyków wykonujących (niekiedy niezwykle trudne i niezwykle efektowne) przeskoki z jednej nogi na drugą, od jednego punktu oparcia do drugiego, bo tylko w ten sposób utrzymać możemy chwiejną równowagę. Żeby wyjaśnić charakter tego balansowania, Derrida porywa się (co zresztą charakterystyczne dla uprawianej przez niego filozofii) na zastosowanie metafory na granicy zrozumiałości i przywołuje wyszperane u Kanta quasi-pojęcie mochlos. Słowem tym starożytni Grecy nazywali drewnianą belkę, której używali jako dźwigni do przemieszczania okrętu albo do otwierania lub zamykania bramy - mochlos to coś, na co napieramy, by wymusić przemieszczenie się czegoś innego. W sensie przenośnym można mówić o takich dźwigniach w historii, moralności lub polityce: „Jeśli pytamy, jak orientować się w historii, w moralności czy w polityce, to rozstrzygnięcia najważniejszych sporów i decyzji orientowały się, jak sądzę, nie tyle wedle celów, co wedle dźwigni. Na przykład opozycja pomiędzy lewicą i prawica, w sensie parlamentarnym, to być może w znacznym stopniu, jeśli nie wręcz całkowicie, konflikt pomiędzy różnymi strategiami dźwigni politycznej (mochlos)” (Derrida, 1984). Pojęcie „orientowania się” Derrida wywodzi tu od Kanta, wskazując zwłaszcza na jego dwie rozprawy poświęcone zagadnieniu orientacji przestrzennej i intelektualnej: przedkrytyczną rozprawę O pierwotnej przyczynie rozróżniania stron w przestrzeni z 1768 roku i tekst Co oznacza: Orientować się w myśleniu z roku 1789 (Kant, 2010; 2012). Złożonego usytuowania problematyki orientacji w Kantowskim polu Anschauung i rozpiętości pomiędzy bierną recepcją danego położenia a dowolnością obieranych schematów nie będziemy tu rozważać, gdyż zaprowadziłoby nas to za daleko; dość rzec, że zagadnienie orientacji rozważane przez Kanta może służyć jako dostateczne usprawiedliwienie dla wprowadzenia przez Derridę metafory balansowania i gimnastyki jako ucieleśnionego doświadczenia ${ }^{1}$ : „Opozycja pomiędzy stroną prawą i lewą nie wynika z żadnej determinacji pojęciowej i logicznej, lecz wyłącznie ze zmysłowej topografii, którą odnieść można jedynie do subiektywnej pozycji ludzkiego ciała” (Derrida, 1984). Pojęcie dźwigni z balansowaniem

${ }^{1}$ Jeśli chodzi o paradygmat ucieleśnionego doświadczenia, por. np. Pokropski, 2013. 
ciała splata się w etymologicznym przejściu od mochlos do (również odnalezionego u Kanta) medycznego terminu hypomochlion, oznaczającego oś obrotu, punkt podparcia, obrotu stawu lub przegubu.

Przejście to Derrida celebruje, przytaczając obszerny fragment z końca Sporu fakultetów, w którym Kant, popadając w idiosynkratyczną gadaninę, na poły się kompromituje, na poły odsłania coś niezwykle istotnego.

Rozważając konflikt fakultetu filozofii z fakultetem medycyny, omówiwszy zdolność duszy ludzkiej do panowania nad swymi chorobliwymi odczuciami, pouczywszy nas o dietetyce, poinformowawszy o własnej hipochondrii, o śnie i o bezsenności, Kant czyni nam następujące zwierzenie, do którego, by uszanować wasz sen, nie dodam ani słowa. Zwracam jedynie uwagę na mochlos i hypomochlion: „Ponieważ bezsenność jest wadą wieku słabowitego, a lewa strona w ogólności słabsza, przeto czułem w niej od roku [kurcze] i drażnienia nader dotkliwe, [...] i musiałem się do rady lekarskiej uciekać [...]. Zniecierpliwiony tedy bezsennością, jąłem się wnet mego stoickiego środka zajęcia mych myśli z usilnością jakim bądź obranym przeze mnie przedmiotem, np. rozważaniem życia Cycerona”. Wzmiankę o słabości lewej strony opatruje Kant przypisem: „Panuje całkowicie błędne przekonanie, że do wyrobienia siły w kończynach wystarczy odpowiednio wcześnie ukształtowany nawyk, by dowolnie wzmocnić lub osłabić jedną z nich, na przykład by ktoś w walce robił szablą prawą lub lewą ręką lub by jeździec, trzymając nogę w strzemieniu nacierał z konia z prawej strony na lewą lub odwrotnie itd. Doświadczenie uczy jednak, że jeśli na przykład obstalowując buty brać miarę z lewej stopy, i jeśli lewy but doskonale układa się do nogi, to prawy okazuje się zbyt ciasny; nie można zatem winić rodziców za nieodpowiednie kształcenie dzieci. Przewaga prawej strony nad lewą objawia się i w tym, że jeśli ktoś chce przejść przez szeroki rów, musi zaprzeć się lewą nogą w ziemię, by zrobić krok prawą; jeśli uczyni odwrotnie, grozi mu wpadnięcie do rowu. Zasadzie tej nie przeczy to, że pruskich piechurów uczy się występować lewą nogą, lecz raczej ją potwierdza; piechur wysuwa bowiem nogę, zyskując jakby hypomochlion, by prawą stroną ciała nadać impet swemu atakowi, który wyprowadza od prawej ku lewej”. (Derrida, 1984; Kant, 2018b: 96; Kant, 1917: 106-107)

Pojęcie hypomochlion - osi dynamicznej równowagi - surowemu Kantowi skojarzyło się ze szkoleniem pruskich piechurów przyuczanych do nadawania impetu swojemu atakowi, nam zaś, podążającym za tekstem Derridy, kojarzy się bardziej z... akrobatyką. Zaiste, dzisiejszy homo academicus wykonywać musi nie lada akrobacje, by, mieszcząc się w granicach wyznaczonych przez wymogi parametryzacji i kategoryzacji, pełnić jeszcze swoją uniwersytecką misję. „W Uniwersytecie Doskonałości - pisze Bill Readings w swych niełatwych do przełknięcia, ale jakże prawdziwych refleksjach 
o kondycji uniwersytetu - nauczyciele i studenci mogą nawet zachować wiarę w kulturę, jeżeli im się tak podoba, pod warunkiem, że ich przekonania będą się przekładać na doskonałe wyniki, a tym samym powodować wzrost ogólnej jakości” (Readings, 2017: 286). Mówiąc jeszcze dosadniej - ten i ów filozof czy filolog może sobie nawet pozostać humanistą, jeśli mu się tak podoba, byleby sprawnie zdobywał punkty i mieścił się w standardach technokratycznej excellence. Dochowanie wierności uniwersyteckim ideałom wymaga dziś wytrzymałości, gibkości i bystrości daleko przekraczających sprawności pruskich piechurów.

Władza nie spada z nieba. Granice pomiędzy nią a wiedzą i kompetencjami humanisty przebiegają wewnątrz nas, wewnątrz naszych akademickich władz, fakultetów i światów. Również odpowiedzialność za to, co dzieje się dziś na uniwersytecie, nie spoczywa wyłącznie na tych, którzy niszczą go z zewnątrz. Jak pisze Zygmunt Bauman, za inwazję technokratów możemy zasadnie winić neoliberalizm i absolutyzację praw rynku, ale to nie Margaret Thatcher spacyfikowała uniwersytety, wysyłając tam swoje wojska, jak niegdyś na Falklandy: „dokonaliśmy tego naszymi własnymi rękoma, rękoma akademików, z ogromnym entuzjazmem, z całym zapałem i pomysłowością, na jaki nas było stać” (Bauman, Donskis, 2013: 139-140). Ponieważ problem kondycji uniwersytetu, który przed nami staje, nie tylko nas dotyka, lecz jest także naszym własnym problemem, nie wolno nam zastygnąć w milczeniu, choćby nawet towarzyszyła mu maestria tanecznych figur. Ciąży na nas obowiązek myślenia i artykułowania tego, czego zasadniczo nie można powiedzieć. Musimy mówić, tańcząc, i tańczyć, mówiąc. Jedno i drugie sprawiać może (i powinno) wrażenie swobodnej ekspresji i dowolności, ale my wiemy, że językiem i mową rządzą surowe reguły, a dynamikę tańca wyznacza bezwzględna (iście Kantowska) logika ciała, określająca osie możliwych obrotów i kierunków ruchu.

\section{0 tym, co mimo wszystko da się powiedzieć. Widmo idei, czyli kilka słów o kondycji uniwersytetu}

Skonstatowaliśmy już - a w każdym razie byliśmy tego blisko - że w rozważaniach na temat autonomii i kondycji uniwersytetu nawiedza nas widmo prawdy. W dalszej części tych rozważań przyjdzie nam stwierdzić, że w dziedzinie tej nawiedza nas też widmo idei - mimo wszystkich znamion kryzysu i upadku uniwersytet jawi się nam wciąż jako ważna i zobowiązująca idea. $\mathrm{Z}$ ideą tą jednak czujemy się bardzo nieswojo. Temu zjawisku nieswojości 
(Unheimlichkeit) poświęcimy teraz nieco więcej miejsca. „Es ist mir unheimlich geworden” (Poczułem się nieswojo) - powiedział Hans-Georg Gadamer, dowiedziawszy się o atakach z 11 września 2001 roku. Nieswojo czują się też członkinie i członkowie dawnej universitas magistrorum et scholarium, którzy stali się zwykłymi pracownikami naukowo-dydaktycznymi zatrudnionymi w jednostkach świadczących usługi edukacyjne. Rewolucja, jaka dokonała się w ich świecie za sprawą agresywnego, neoliberalistycznego modelu doskonałości (excellence), przybiera dla wielu z nich postać tajemniczego „płynnego zła” (Bauman, Donskis, 2013: 131-167; 2016). Zaiste, jako podmioty dociekania i nauczania (jeśli można tu jeszcze mówić o podmiotach) są oni bliscy śmierci. Ale taka właśnie - i do tego winniśmy się przyzwyczajać - jest kondycja istot nawiedzanych przez duchy.

Nawiedzany - jak pisze Derrida w Widmach Marksa - musi nauczyć się żyć.

Jeśli uczenie się życia pozostaje czymś, co należy dopiero zrobić, to może się ono zdarzyć jedynie pomiędzy życiem i śmiercią. [...] To, co dzieje się pomiędzy tymi dwoma [stanami] [...] może jedynie utrzymywać się, podtrzymując rozmowę [s'entretenir] o jakimś widmie. Trzeba będzie zatem nauczyć się duchów. (Derrida, 2016: 12)

Jeśli chcemy odnieść korzyść z powrotu wypartego, musimy przyjąć zasady Derridiańskiej hauntologie (widmontologii) i przystać na tę osobliwą propozycję. Świat wypadł z ram, wyszedł z formy lub, jak zwichnięta kość, wyskoczył ze stawu (the time is out of joint - woła Hamlet; W. Szekspir, Hamlet, akt I, scena 5; Derrida, 2016: 19). W chwili, gdy powstaje ten tekst czyli w dobie pandemii - nic nie jest bardziej oczywiste.

Uczelnie wyższe są dziś miejscem, w którym pojawiają się rozmaite widma, a my - pracownicy tych uczelni - musimy nauczyć się żyć w niegasnącym zdumieniu z powodu tych nadzwyczajnych zjawisk. Jesteśmy nawiedzani przez widma, ale przecież, jako humaniści, sami jesteśmy częścią zjawiska, które obserwujemy - inaczej mówiąc, sami jesteśmy widmami. Znaczymy tyle co nic i prawie wcale nas nie ma. Po pierwsze, dlatego że nasze roszczenie do moralnej integralności, wynikające jakoby z przedmiotu, którym się zajmujemy, i będące źródłem kompetencji niezbędnych do pełnienia roli „modelu racjonalności wspólnoty politycznej”, okazało się absurdalne. „Każdy, kto spędził choć trochę czasu na uniwersytecie - pisze Bill Readings, rozwiewając nasze złudzenia - wie, że nie jest on wzorem wspólnoty i że trudno o zbiorowość równie małostkową i pełną złośliwości jak społeczność na typowym wydziale uniwersyteckim” (Readings, 2017: 273, 274). 
Po drugie, dlatego że, gdyby nawet jakimś cudem przysługiwały nam tego rodzaju cudowne kompetencje estetyczne i moralne, predestynujące nas do wcielania „idei uniwersytetu”, dążenie do realizacji tego rodzaju rojeń w dobie parametryzacji jest mrzonką i stratą czasu oraz, co najważniejsze, cennych funduszy, dystrybuowanych zgodnie z regułami wolnego rynku i precyzyjnej oceny wskaźników excellence. Pozbawia nas ostatnich złudzeń Marek Kwiek, badacz uprawiający refleksję nad transformacją uniwersytetu w pełnej zgodności z nowym, technokratycznym paradygmatem, wymieniwszy długą listę osób, instancji i instytucji wspierających jego badania:

Analizy naukowe dotyczące przyszłości uniwersytetu (w tym tradycyjne, humanistyczne rozważania o idei uniwersytetu, które mogłyby pozostawać w tradycji myślenia o uniwersytecie wyznaczanej przez takie nazwiska, jak: Wilhelm von Humboldt, John Newman, José Ortega y Gasset, Karl Jaspers, Max Weber czy Jürgen Habermas [...]) pozostają dzisiaj w świecie niezwykle rozproszone i w zasadzie nie posługują się dominującą pojęciowością badań nad szkolnictwem wyższym, ich kluczowymi pojęciami, a co może najważniejsze, w bardzo ograniczonym stopniu odwołują się do badań empirycznych, w tym do europejskich danych porównawczych. Nie wychodzą też z reguły poza wąski, dyscyplinarny dyskurs socjologii, pedagogiki czy historii instytucji. Z tego między innymi powodu ich społeczna, kulturowa (oraz polityczna) siła oddziaływania jest minimalna. (Kwiek, 2010: 22)

Nie chodzi tu o to, by się do humanistyki ostatecznie zniechęcić, lecz o to, by nauczyć się żyć w niesłabnącym zdumieniu własną nieznacznością, by na podobieństwo średniowiecznych mnichów nieustannie kontemplować własną marność.

A jednak się kręci - chciałoby się powiedzieć wraz z Galileuszem eppur si muove. A jednak nawiedza nas idea prawdy, wiedzy, poznania, nawiedza nas widmo filozofii - owego „niższego fakultetu” Kanta, który, w spolszczeniu współczesnego Kantowi Józefa Bychowca, „trudni się tylko interesem umiejętności” (Kant, 2018a: 37; por. przypis 8). Słowo „umiejętność”, o staropolskim rodowodzie (ostało się ono na przykład w nazwie Polskiej Akademii Umiejętności), zawiera w sobie jedność zdolności teoretycznych i praktycznych, jedność, którą (po długim rozdziale w historii kultury i myśli europejskiej) odnalazł i której znaczenie docenił właśnie Immanuel Kant (Żardecka, 2010). Jak podaje słownik Brücknera (1984: 594), um odpowiada zarówno za praktyczną umiętność, czyli umiejętność, jak i za teoretyczną zdolność roz-umu, który każe nam z-umieć (zdumieć) się czymś, by potem z d-umq pokazywać innym to, co znaleźliśmy. 
„U”, które tak wyraźnie słuchać w um ma, według Brücknera, ten sam pień co jaw w zjawić się. Zatem oddawać się pasji rozumu, pasji odkrywania i nauczania to tyle, co stać w samym środku zjawiania się tego, co ukazuje się nam w oglq̨dzie (Anschauung). Nie od rzeczy jest tu przywołanie słowa interes (którego znaczenie zostało ostatnimi czasy zredukowane do podejrzanych, merkantylnych manipulacji zmierzających do utowarowienia wszystkiego). Łacińskie interesse to być w samym środku wydarzenia (na przykład bitwy), brać w czymś udział z najwyższym możliwym zaangażowaniem. Uczony, otwierając się na to, co się mu jawi w przedmiocie badań i czym jest żywo zainteresowany, uczestniczy w pojawianiu się tego przedmiotu, angażuje się zatem głównie i przede wszystkim w pojawianie się zjawionego, dopiero wtórnie - w naukę z jej procedurami i metodami. Na los jego zainteresowań, na to, czy zostaną rozwinięte, czy ograniczone lub ukrócone, ma oczywisty wpływ zestaw interesów zbiorowości, w której badacz funkcjonuje. Wobec jedności rozumu spekulatywnego i praktycznego, o której mówi Kant, oczywista staje się głoszona przez Habermasa jedność „wiedzy i interesu”:

Także interes rozumu spekulatywnego byłby uzasadniony jedynie przez to, że rozum teoretyczny pozostaje w służbie rozumu praktycznego, nie będąc przy tym pozbawionym swej własnej intencji poznania ze względu na samo tylko poznanie. Do [realizacji] interesu poznawczego potrzebuje on nie tylko wsparcia spekulatywnego użycia rozumu jako takiego, lecz także związku czystego rozumu spekulatywnego z rozumem czysto praktycznym, i to pod kierunkiem tego praktycznego rozumu: „Nie można wcale wymagać od czystego rozumu praktycznego podporządkowania się rozumowi spekulatywnemu, ponieważ wszelki interes jest ostatecznie praktyczny, a nawet interes właściwy rozumowi spekulatywnemu jest warunkowy i jedynie w praktycznym użytku zupełny” (Habermas, 1991: 250; Kant, 1984: 197).

Nie stanowi zatem problemu sam interes praktyczny, interesowność administratorów uniwersytetu czy instrumentalizacja teorii - głównym problemem jest to, jak ustalą się relacje pomiędzy rozumem teoretycznym i praktycznym, w jakie konstelacje ułożą się stosunki pomiędzy nimi, w jakich złożonych grach społecznych i językowych rozgrywane będą wzajemne pomiędzy nimi powiązania. W tym sensie performatywność tworzącego akademię dyskursu wiedzy i wyznania wiary, prowokuje Jacques’a Derridę do postawienia na końcu swojej rozprawy wielkiego pytania o „sens sensu” (Derrida, 2015: 99). Performatywność jest przypisana do dążenia do wiedzy, a dziś, w ponowoczesności, stała się jedynie bardziej widoczna. Trudność stanowi natomiast uzasadnienie prawomocności dyskursu akademickiego 
czy zwłaszcza metaakademickiego, o które martwi się Derrida w tym samym końcowym fragmencie Uniwersytetu bezwarunkowego.

Skoro tak się ma rzecz z uczonym, który ma do czynienia „z interesem umiejętności, to jest prawdy, gdzie rozum otwarcie mówić prawo mieć musi”, i dlatego trudniący się myśleniem musi zachować wolność, gdyż „rozum [...] z przyrodzenia swego jest wolny, i żadnych rozkazów, aby coś mieć za prawdę [...] nie przyjmuje” (Kant, 2018: 37-38), to należy teraz dopytać o bliższe uzasadnienie autonomii uniwersytetu. W literaturze na ten temat $\mathrm{z}$ ostatnich dziesięcioleci - nawet w tej najbardziej krytycznej wobec neoliberalnej „reformy” szkolnictwa wyższego - ustalił się pewien schemat interpretacyjny, zgodnie z którym autonomię uniwersytetu w jego nowożytnej postaci uzasadnia roszczenie do prawdy wywodzące się z idealizmu niemieckiego oraz polityczny wybór liberalnej wizji stosunków pomiędzy uniwersytetem a państwem, którego dokonał Wilhelm von Humboldt (opowiadając się za wizją uniwersytetu Friedricha Schleiermachera). Jednak roszczenie do prawdy absolutnej upadło, między innymi dlatego, że nie do utrzymania okazał się postulat idealnego podmiotu, ducha obiektywnego i systemu-podmiotu, scalającego całość ludzkiej wiedzy (por. Habermas, 1985: 703; Lyotard, 1997: 117)². Z kolei gwarantujący autonomię układ pomiędzy państwem narodowym a uniwersytetem nie tylko się rozpadł, ale wręcz jest na naszych oczach „ścierany w pył przez transnarodowe korporacje”. Wynikać ma z tego, zdaniem technokratów, że dążenie do wiedzy i mądrości dla niej samej zastąpić należy dążeniem do uzyskania maksymalnych korzyści za pomocą wielu wysoce wyspecjalizowanych, technologicznie i (lub) społecznie przydatnych dyskursów.

Odrzucenie uniwersytetu jako idei jest konsekwencją zanikania państwa narodowego oraz dyskredytacji idealizmu niemieckiego z jego przekonaniem o istnieniu i wyższości obiektywnych i absolutnych form ducha. Według Lyotarda dawny uniwersytet, w którym rozwijało się spekulatywne życie Ducha, zostaje zastąpiony przez uniwersum gier językowych, w którym „językowa gra nauki zostaje zrównana z innymi” i w związku z tym „nie może legitymizować innych gier językowych” (Lyotard, 1997: 112-113, 116). Mankamentem tej sytuacji, jak stwierdza Lyotard - a wraz z nim Zygmunt Bauman, Leonidas Donskis i wielu innych autorów relacjonujących rozgrywający się

2 "It is interesting to note the parallelisms in Lyotard's critique of Wilhelm von Humboldt and the German Idealists in general and Habermas' critique of Jaspers in his classic book". Kwiek, 2006: 12. 
na naszych oczach dramat uniwersytetu - jest to, że ducha absolutnego zastąpił neoliberalny, technokratyczny „ogólny duch skuteczności”, a konsekwencją wycofywania się państwa z mecenatu nad działalnością uniwersytecką jest jej uzależnienie od kaprysów właścicieli kapitału: „gry języka naukowego stają się grami bogatych [...]. Zarysowuje się znak równości między bogactwem, skutecznością a prawdą” (Lyotard, 1997: 128; por. Bauman, Donskis, 2013; Donskis i in., 2019).

Pomimo że zdajemy sobie sprawę z problematyczności idei prawdy, podmiotu, obiektywności wiedzy itp., pomimo że zdajemy sobie sprawę z faktu, że odpowiedzialne dotąd na szkolnictwo wyższe państwo narodowe zanika i pozbywa się swoich funkcji, pomimo że zdajemy sobie sprawę z destrukcyjnego wpływu tych czynników na kondycję uniwersytetu i nas samych, jako przejęci swoją rolą, nieco groteskowi humaniści nadal niestrudzenie drążymy pewne tematy - nadal zjawiamy się w stechnicyzowanym, sparametryzowanym świecie rynkowym, by o czymś powiedzieć.

\section{Model Humboldtowski dzisiaj: idea uniwersytetu Karla Jaspersa}

O tym, że tradycja Humboldtowska żywa jest w Polsce także i dziś, w dobie kryzysu uniwersytetu, świadczy opublikowane niedawno polskie wydanie Idei uniwersytetu Karla Jaspersa (2017) ze znakomitym streszczająco-komentującym wstępem Tadeusza Gadacza (2017). Jeśli czytać dzieło Jaspersa przez pryzmat impulsu romantycznego, obecnego w tradycji uniwersytetu Humboldta, widać wyraźnie, że widmo idei uniwersytetu, zstępujące z kosmosu niemieckiego idealizmu, w gruncie rzeczy zakorzenione jest w obecnym u Schleiermachera i Humboldta romantycznym rozumieniu Bildung: tekst Jaspersa opowie nam swoją historię, jeśli spytamy go: Kto i kogo ma kształcić? „Przesłanką dla nauki jest kierownictwo idei” (Jaspers, 2017: 49). Znaczy to także i przede wszystkim, że „Nauka potrzebuje kierownictwa”, które „musi odbywać się z wnętrza, z podwalin samej nauki, a właściwie ze źródła obejmującego wszelką naukę, a jest nim bezwarunkowa wola wiedzy” (s. 51, 53). Kierownictwo to - mówi Jaspers językiem idealizmu, ale całkiem w duchu indywidualizmu romantycznego -

[...] pochodzące z Jedni transcencencji nie jest jednak w żadnym wypadku jednoznaczne. Nikt nie może pojmować go jako jedynie i dla wszystkich prawdziwego i nikt nie może wejść w jego posiadanie. Realizuje się ono niejako w dialogu między myślącym człowiekiem a wieloznacznością poznawalnego. Jest jak próba i jak akt odwagi. (Jaspers, 2017: 54) 
Piastunami kierownictwa, którego potrzebuje nauka, są ludzie uformowani - właściwa uniwersytetowi jest formacyjność naukowa, oznaczająca „zdolność w danej chwili do pozbycia się własnych wartościowań na rzecz obiektywnego poznania” (Jaspers, 2017: 66). Nosicielami woli wiedzy, źródła uniwersytetu, są zarówno nauczyciele, jak i uczniowie - „pierwotna wola wiedzy jest wszechwładną motywacją w życiu uniwersytetu, zarówno u nauczycieli, jak i u uczniów” (s. 77). Istotę wychowania opisuje Jaspers w trzech stopniach czy poziomach realizacji ideału. Opis ten pozostaje w zgodzie z postulatem jedności badania i nauczania. Pierwszy stopień to wychowanie scholastyczne, polegające na odgórnym, bezosobowym przekazywaniu wiedzy zastanej. Następny stopień to wychowanie mistrzowskie - jest to wprawdzie relacja osobowa, ale nadal hierarchiczna, opierająca się na autorytecie. Najwyższy stopień realizacji ideału wychowania jest już zdecydowanie Humboldtowski, oparty na wizji unikalnego indywiduum: jest to wychowanie sokratejskie, w którym

[...] uczeń i nauczyciel znajdują się na tym samym poziomie. Obaj są z założenia ludźmi wolnymi. Nie ma utrwalonej wiedzy, ale panuje bezgraniczność pytań i niewiedza w sensie absolutnym. Tym samym rośnie aż do najwyższej skrajności osobista odpowiedzialność, której nic nie łagodzi. Wychowanie ma charakter majeutyczny, to znaczy pomaga się w narodzinach sił ucznia, budzi tkwiące w nim możliwości, ale nigdy nie narzuca mu się niczego z zewnątrz. (Jaspers, 2017: 84-85. 85)

W postulacie „bezgraniczności pytań” ujawnia się erotetyczny charakter myślenia, właściwy filozofii egzystencjalnej Jaspersa, ale też i filozofii Martina Heideggera (Sobota, 2012: 29n). Z tej perspektywy można by zaryzykować twierdzenie, że Heideggerowska ontologia pytania o bycie jest przeniesieniem w samo serce filozofii romantycznego, Humboldtowskiego rozumienia individuum i jego drogi do samodoskonalenia, które legło u podstaw dziewiętnastowiecznego modelu uniwersytetu. W tym kontekście kojarzenie romantycznego kultu autonomii indywiduum z faszystowskim kultem wodza i sprowadzanie pytajności myślenia do treści nieszczęsnego wykładu rektorskiego Heideggera z 27 marca 1933 roku o „samopotwierdzaniu się niemieckiego uniwersytetu” byłoby, mówiąc oględnie, sporym nadużyciem, choć sam ten tekst jest interpretacyjnie niedoceniany i domaga się gruntownej analizy (Sieg, 2005: 16). Das Volk, który samopotwierdza się za pośrednictwem uniwersytetu w mowie Heideggera, wzięty jest ze świata bliskiego ideologii NSDAP, ale niewiele ma to wspólnego z ideałem, po który Heidegger sięga. Być może 
najdobitniej na paradoksalność zarzutów, że obrona idei uniwersytetu, zawarta w opublikowanej w roku 1923 i dwukrotnie wydawanej po wojnie książce Jaspersa, jest podejrzanie bliska idei supremacji narodu, stanowiąc anachroniczny wyraz nostalgii za idealizmem niemieckim, wskazuje opinia jednego ze współczesnych nam autorów amerykańskich, który pisze, że w obliczu niszczącej fali neoliberalnej biurokratyzacji i merkantylizacji ośrodków akademickich jedynym systemem, który się wobec niej ostaje, jest właśnie uniwersytecki system niemiecki, w którym głównym ośrodkiem zarówno władzy uniwersyteckiej, jak i zarządzania finansami jest katedra profesorska (Lehrstuhl) (Van Loon, 2019: 164-166). Jest paradoksem, że, jak pisze ów autor, czynnikiem, który pozwala niemieckim uniwersytetom tak skutecznie opierać się fali neoliberalnego obrachowywania, jest konstrukcja prawna obecnego państwa niemieckiego, która powstała po drugiej wojnie światowej jako zabezpieczenie przed powtórzeniem się przypadku III Rzeszy.

Dominacja katedry profesorskiej - ze wszystkimi jej dobrymi i złymi konsekwencjami - świadczy o żywotności idei uniwersytetu, zasadzającej się na romantycznym kulcie indywiduum. Jaspers oczywiście, jak mówiliśmy, jest realistą i jego Idea uniwersytetu pełna jest uwag o nieziszczaniu się idei i o degeneracji akademii. „Instytucja jako taka nigdy nie zadowala” (Jaspers, 2017: 116). Jednak w porządku idei zarówno nauczający, jak i nauczani mają być jednostkami wybitnymi, ukształtowanymi przez habitus naukowości (s. 66), dla których ich pozycja na uniwersytecie nie ma być kwestią obrony prywatnych interesów, lecz pasji odkrywania prawdy. Niezwykle ważna w tym kontekście jest, zdaniem Jaspersa, gradacja uzdolnień (s. 145-147) predestynujących do udziału w życiu uniwersytetu: podstawę ich oceny stanowią widoczne przesłanki uzdolnień, takie jak pamięć, zdolność zachowania uwagi, zdolność uczenia się itd. Trudniej uchwytna, ale nadrzędna jest właściwa inteligencja oraz swoista duchowość, etos inteligencji, zainteresowania poznawcze, „miłość do sprawy, natchnienie przez idee, prawdziwość, entuzjazm poznawania” (s. 146). Nade wszystko jednak istotnym miernikiem kwalifikacji predestynujących do wspólnoty uniwersyteckiej są zdolności twórcze, które pozostają „całkowicie poza możliwościami obiektywnej oceny” (s. 146). Jakkolwiek brzmiałoby to w uszach dzisiejszego czytelnika, Jaspers mówi tu wprost o geniuszu i jego nieuchwytności. Geniusz nie jest gotową dyspozycją, łatwo go zmarnować; by go rozwinąć, niezbędny jest „etos, wola, pilność, rzemiosło”, ale to geniusz „stwarza pradoświadczenia, pierwotne idee i kształty”; „żyjemy z tego, co stworzył w nas geniusz, i z transpozycji 
genialnego dzieła w sferę powszechnej wiedzy i powszechnego rozumienia”. Inaczej mówiąc, geniusz jest warunkiem niezbędnym owej otwartości na jawienie się przedmiotu, o której mówiliśmy na początku. Jak można stąd wywnioskować, uniwersytet jest właściwym miejscem dla geniuszu, choć, jak mówi Jaspers, nikt „nie jest całkowicie geniuszem, co najwyżej genialnym człowiekiem. Ten ogień płonie mniej lub bardziej intensywnie w każdym człowieku, ale żaden człowiek nie jest bogiem”. Dla owego świętego ognia zastrzeżone jest miejsce w akademii. W tej świątyni otwartości na prawdę wolny geniusz nauczających ma spotykać się z wolnym geniuszem nauczanych. Pytając, do jakich studentów kieruje się nauczanie uniwersyteckie, Jaspers odpowiada: „Jedynie z pozoru do wszystkich, ale w istocie - do najlepszych”. Jeśli ktoś dostrzegłby tu przejaw „elitarnego w swej wizji kształcenia mieszczańskiego pesymizmu kulturowego”, który potępia umasowienie wykształcenia uniwersyteckiego i wyklucza konieczność potrojenia współczynnika skolaryzacji - która przydarzyła się w Polsce po roku 1989 - to wypadałoby spokojnie dopowiedzieć, że pomiędzy szerokim dostępem do kształcenia na poziomie uniwersyteckim a zastrzeżeniem go dla geniuszu nie ma istotnej sprzeczności. Ogień geniuszu, jak mówi Jaspers, płonie w każdym. Istotą uniwersytetu jest kształcenie przez mistrzów tych, którzy potem zostaną ich uczniami i następcami, na zasadzie możliwie jak największej równości nauczających i nauczanych, a wszystko inne - mówiąc językiem stosownym do dzisiejszych uwarunkowań - jest produktem ubocznym. Ci, którzy są mniej zdolni lub przywiązują mniejszą wagę do płonącego w nich ognia, otrzymują na uniwersytecie wykształcenie, uczestnicząc - na miarę swoich chęci i możliwości - w ogniu, który płonie w innych, kończąc studia, zdobywając niezbędną formację zawodową, pod warunkiem, że sercem, centrum, solą uniwersytetu są ci, w których ten ogień płonie możliwie najbardziej. A płonąć może on pod warunkiem, że najlepszym stworzono warunki materialne i instytucjonalne do „twórczego próżnowania i kontemplacji” (s. 154). Jeśli ich nie ma, wiedza degeneruje się w zbiór mechanicznie przyswajanych formuł i procedur niezrozumiałych ani dla nauczających, ani dla nauczanych, poznanie staje się pseudopoznaniem, nauka pseudonauką, tragikomiczną grą na punkty.

Niech nikt nie oponuje, że wszelkie idee to mrzonki, a rzeczywistość wygląda zupełnie inaczej. Mówimy wszak nie o rzeczywistym uniwersytecie, lecz o idei, która nas nawiedza, jak nawiedzają nas inne duchy przeszłości, my zaś - jak mówi Derrida - półżywi od życia w rzeczywistości, uczymy się duchów. 


\section{Urealnienie idei: osobliwość, dyssens, paralogia i koszmar fałszywej indywidualności. Readings, Lyotard, Bauman i Donskis}

Wziąwszy poprawkę na realizm, możemy teraz odnieść kategorie romantycznego kultu indywiduum i geniuszu, stanowiącego fundament uniwersytetu od Humboldta do Jaspersa, do interpretacji sytuacji uniwersytetu proponowanych przez tych, którzy chcą jej ponowoczesnego urealnienia. Skoro - jak sugeruje Bill Readings w podsumowaniu swoich smutnych rozważań - mamy zamieszkiwać w ruinach uniwersytetu, pomni na to, że „przeszłość nie zostaje wymazana, lecz nawiedza teraźniejszość" (Readings, 2017: 258), to musimy przywyknąć do tego, że w nowych okolicznościach wszelka wspólnota w tym także wspólnota uniwersytecka - jest nieprzejrzysta i niedomknięta, nękana niedopowiedzeniami i niezrozumieniem; stanowią ją nie podmioty, lecz osobliwości (Readings, 2017: 279). Nawiązując do tej - sformułowanej przez Agambena - wizji wspólnoty złożonej z osobliwości, w której wszelka solidarność i zobowiązania etyczne są tymczasowe, a więzi doraźne, Readings chce nam powiedzieć, że w dzisiejszej akademii nauczający i nauczani nie rozumieją się ani w swoich własnych gronach, ani nawzajem; wspólnota uniwersytetu jest więc wspólnotą dyssensu, inny pozostaje inny. Kształcenie niegdyś romantyczne Bildung - polega teraz na tym, że „studenci zawsze do pewnego stopnia świadomi są inności nauczyciela” (Readings, 2017: 283). Czy jednak ta osobliwa sytuacja, w której przekazywanie i nabywanie wiedzy ma polegać na niezrozumieniu, może przynieść nam jakąkolwiek korzyść, jeśli nie będzie nas nawiedzać idea osobliwości jako samodoskonalenia się i geniuszu, otwartego od wewnątrz na prawdę tego, co mu się jawi w odkrywanym i przyswajanym przedmiocie wiedzy? W gruncie rzeczy wydaje się, że zatoczyliśmy pełne koło - odkrywając osobliwości zamiast podmiotów, wracamy do Humboldtowskiej celebracji wyjątkowości indywiduów, które, dążąc do własnej, niepowtarzalnej doskonałości, na coś się otwierają. „W sali wykładowej Myślenie pojawia się jako trzeci element obok nadawcy i odbiorcy” (Readings, 2017: 241). To już coś, nawet jeśli nie dane jest nam wiedzieć, czym owo myślenie jest. „Myślenie nie funkcjonuje jako odpowiedź, lecz jako pytanie”, co ma zapobiec „konstytuowaniu się mistycznej ideologii prawdy”. To ważne, skoro, jak pamiętamy, prawda dawno została osądzona i skazana za „zbrodnie przeciwko ludzkości”. Czegóż jeszcze możemy się jednak spodziewać po takim Myśleniu, po takim kształceniu? 
„Oddanie sprawiedliwości Myśleniu, słuchanie naszych rozmówców oznacza próbę usłyszenia tego, co samo nie może być wypowiedziane, ale co próbuje dać się usłyszeć” (Readings, 2017: 240. 245). Tylko tyle. Może tyle wystarczy. Musi wystarczyć.

Podobną wizję proponuje nam Jean-François Lyotard w swej Kondycji ponowoczesnej. Skoro niemożliwy jest już ten rodzaj uprawomocnienia władzy państwowej przez wiedzę, który polegał na Bildung jako na wykształceniu „w pełni prawomocnego podmiotu wiedzy i społeczeństwa” (Lyotard, 1997: 100), gdyż nie można, jak niegdyś Humboldt, odwołać się do Ducha czy Idei, a nauka rozpadła się na nieskończony ciąg gier językowych, to wiedza nie może mieć żadnego stałego, solidnego przedmiotu, a jej jedynym kryterium jest technokratyczny „przyrost mocy”, któremu podporządkowany jest przepływ funduszy przeznaczonych na badania. Postęp w nauce polega na szukaniu kontrprzykładów i paradoksów, prym w niej wiodą ci, którzy są w stanie czymś zaskoczyć. Dyskurs nauki rozchwiany jest do tego stopnia, że ostatecznie nawet o logice skuteczności nie może być mowy; jej zadaniem jest teraz szukanie instabiliów (Lyotard, 1997: 131. 133. 150).

[P]onowoczesna nauka tworzy teorię własnej ewolucji jako ewolucji nieciągłej, katastroficznej, nie dającej się wyprostować, paradoksalnej. Zmienia sens słowa wiedzieć i mówi, w jaki sposób ta zmiana może się dokonać. Wytwarza już nie wiedzę (du connu) lecz nie-wiedzę (de l'inconnu). I sugeruje model legitymizacji nie mający nic wspólnego z większą skutecznością, ale odwołujący się do różnicy rozumianej jako paralogia. (Lyotard, 1997: 161)

Cokolwiek rozumie Lyotard przez termin paralogia - nasuwający się odpowiednik znaczeniowy to termin medyczny, oznaczający schizofreniczne zaburzenie logiczności myślenia - to jego sprzeciw wobec wszelkiej jednoznaczności znów kieruje nas w stronę widma idei: paradoksalność musi mieć jakieś granice. Skoro tak silnie narzuca nam się niepowtarzalność produktów wiedzy, to powstaje pytanie, czy nie musimy powrócić do idei niepowtarzalności i wyjątkowości poznających i ich możliwej wspólnoty. Do idei tej powrócilibyśmy, wypatrując, czy nie zrodzi ona jakiejś choćby prowizorycznej podstawy wiedzy, choćby po to, by ta prowizoryczna podstawa pomogła ocalić tak drogą wszechwładnemu Rynkowi skuteczność, która wymyka mu się z rąk tym bardziej, im bardziej na nią nastaje.

Niepowtarzalność ta - jak niegdyś społeczeństwo otwarte Poppera - ma w technokratycznej dyktaturze neoliberalizmu swoich wrogów, i wrogów tych identyfikują Zygmunt Bauman i Leonidas Donskis. Jak twierdzą ci autorzy, w dobie „konsumującego uniwersytetu” (można chyba przyjąć, 
że termin ten w języku angielskim oznacza zarówno uniwersytet pochłonięty przez konsumpcję, jak i uniwersytet konsumujący, to jest pochłaniający i unicestwiający sam siebie i tych, którzy z nim mają do czynienia) utrzymująca go rzeczywistość społeczna, kierująca się zasadą TINA (There Is No Alternative - nie ma innego wyjścia, musisz podporządkować się prawom Rynku), opiera się na pewnej koszmarnej właściwości tworzących ją jednostek. Właściwość ta polega na posiadaniu fikcyjnej, „domyślnej” indywidualności, stanowiącej odwrotność świadomych i wolnych wyborów (individuality by default). Udajemy, że realizujemy Marksowską utopię wyzwolenia z alienacji, stając się kreatywnymi pracownikami, płodnymi artystami, odkrywczymi badaczami i rozwiązując wszelkie problemy świata, a w rzeczywistości świat, który nas otacza, kontroluje naszą pamięć, język i myślenie i ujednolica nas do stopnia, o którym śniły dawne systemy totalitarne. Mamy być dokładnie tacy, jak się tego od nas oczekuje, i tacy jesteśmy. Sytuacja ta przypomina dystopie znane z książek Zamiatina, Orwella i Huxleya. Orwellowska nowomowa miała sprawić, że nikt już nie będzie w stanie zrozumieć dramatów Szekspira. Wymazanie dziejów zbiorowej pamięci i kultury prowadzi do kolektywnego solipsyzmu. My Zamiatina kreśli wizję „śmierci klasyki i śmierci przeszłości. W kontekście dystopii Zamiatina, Huxleya i Orwella paradoksalny zwrot totalitaryzm technokratyczny byłby pleonazmem, gdyż żadna inna postać totalitaryzmu nie wydawała się im możliwa” (Bauman, Donskis, 2013: 133). Kolejną dystopijną wizją, obrazującą sytuację fałszywej „domyślnej” indywidualności, jest oświeceniowa pra-utopia Louisa Sebastiena Merciera Rok 2440, opisująca przyszły świat, w którym nie ma miejsca na historię; zaniechano nauczania i studiowania historii, gdyż racjonalny człowiek przyszłości nie może zajmować się przeszłością, pełną przesądów i zacofania. Pseudoindywidualizm radosnej, pozbawionej odniesień teraźniejszości symbolizuje przywoływana przez Donskisa scena z filmu Żywot Briana, w której bohater, mylnie brany przez tłum za Jezusa, widząc wiwaty na swoją cześć, woła do tłumu: „Ależ wy wszyscy jesteście indywidualni! Jesteście różni!”, na co tłum ochoczo powtarza: „Tak, jesteśmy indywidualni!”. Tylko jeden jedyny głos z tłumu mówi: „Ja nie”.

Może warto byłoby dać się nawiedzić idei uniwersytetu Humboldta i Jaspersa, by wykształcić w sobie i innych prawdziwą indywidualność, umożliwiającą odzyskiwanie pamięci i rozumienie dramatów Szekspira. Bez niej może się okazać, że paralogia nauki jest prawdziwym szaleństwem, wiodącym do dystopii. Na korzystanie z niezbędnych przywilejów starożytnej schole (Żardecka, 2010; Bourdieu, 2006: 20n), z czasu na „twórcze 
próżnowanie i kontemplację” (Jaspers, 2017: 154), nie jest jeszcze za późno, choć czas ten kurczy się dziś nieubłaganie wraz ze światem, który go umożliwiał. „Poświęćcie temu czas - mówi Derrida, kończąc swe refleksje o uprawianiu Nauk Humanistycznych - ale pośpieszcie się z uczynieniem tego, bo nie wiecie, co was czeka” (Derrida, 2015: 100).

\section{Literatura}

Aron, R. (1983). Mémoires. Paris: Julliard.

Bauman, Z., Donskis, L. (2013). Moral Blindness: The loss of sensitivity in liquid modernity. Cambridge: Polity Press.

Bauman, Z., Donskis, L. (2016). Liquid Evil. Cambridge: Polity Press.

Beauvoir, S. de (1954). Les mandarins. Paris: Gallimard.

Benda, J. (1927). La trahison des clercs. Paris: Grasset.

Benda, J. (2014). Zdrada klerków, tłum. M. Mossakowski. Warszawa: Wydawnictwo Krytyki Politycznej.

Bourdieu, P. (1984). Homo academicus. Paris: Editions du Minuit.

Bourdieu, P. (1988). Homo academicus. Stanford: Stanford University Press.

Bourdieu, P. (2006). Medytacje pascaliańskie, tłum. K. Wakar. Warszawa: Oficyna Naukowa.

Brückner, A. (1985). Słownik etymologiczny języka polskiego. Warszawa: Wiedza Powszechna.

Derrida, J. (1984), Mochlos ou le conflit des facultés. Conférence prononcée en anglais le 17 avril 1980 à l’Univeristé de Columbia (New York), lors du centenaire de sa Graduate School et après d'un Doctorat Honoris Cause [Paru dans Philosophie no 2, avril 1984. Paris: Minuit], redaprenderycambiar.com.ar/derrida/frances/mochlos.htm dostęp: 15.03.2020.

Derrida, J. (2015). Uniwersytet bezwarunkowy, tłum. K.M. Jaksender. Kraków: Libron.

Derrida, J. (2016). Widma Marksa, tłum. T. Załuski. Warszawa: Wydawnictwo Naukowe PWN.

Donskis, L., Sabelis, I., Kamsteeg, F., Wels, H. i in. (red.) (2019). Academia in Crisis. The rise and risk of neoliberal education in Europe. Leiden-Boston: Brill Rodopi.

Ferry, L. (1979) i in. (red.), Philosophies de l'Université. Idealisme allemand et la question de l'Université: textes de Schelling, Fichte, Schleiermacher, Humboldt, Hegel. Paris: Payot.

Gadacz, T. (2017). Wstęp do wydania polskiego. Karla Jaspersa idea uniwersytetu. W: K. Jaspers, Idea uniwersytetu, tłum. W. Kunicki (s. 11-27). Warszawa: Narodowe Centrum Kultury.

Habermas, J. (1985). Die Idee der Universität - Lernprozesse. Zeitschrift für Pädagogik, 32, 703-778.

Habermas, J. (1991). Erkenntnis und Interesse. Frankfurt a. M.: Suhrkamp.

Heidegger, M. (1983). Die Selbstbehauptung der deutschen Universität. Das Rektorat 1933/34: Rede, gehalten bei der feierlichen Übernahme des Rektorats der Universität Freiburg i. Br. am 27.5.1933. Frankfurt a. M.: Klostermann. 
Jaspers, K. (2017). Idea uniwersytetu, tłum. W. Kunicki. Warszawa: Narodowe Centrum Kultury.

Kant, I. (1917). Der Streit der Facultäten in drei Abschnitten. W: I. Kant. Gesammelte Schriften (s. 1-116), Bd. 7, hrsg. von der Königlichen Preußischen Akademie der Wissenschaften. Berlin: Verlag Georg Reimer.

Kant, I. (1984). Krytyka praktycznego rozumu, tłum. J. Gałecki. Warszawa: Państwowy Instytut Wydawniczy.

Kant, I. (2003). Spór fakultetów, tłum. M. Żelazny. Toruń: Rolewski.

Kant, I. (2010). O pierwotnej przyczynie rozróżniania stron w przestrzeni. W: I. Kant. Dzieła zebrane, t. 1: Pisma przedkrytyczne (s. 801-810). Toruń: Wydawnictwo Naukowe UMK.

Kant, I. (2012). Co oznacza: Orientować się w myśleniu. W: I. Kant. Dzieła zebrane, t. 6: Pisma po roku 1781 (s. 139-154). Toruń: Wydawnictwo Naukowe UMK.

Kant, I. (2018a). Spór fakultetów, tłum. J.W. Bychowiec, oprac. K. Kaśkiewicz i T. Kupś. Studia z Historii Filozofii, 1 (9), 35-41.

Kant, I. (2018b), Józefa Władysława Bychowca przekład Sporu fakultetów Immanuela Kanta. W: K. Kaśkiewicz i T. Kupś (red.), Recepcja filozofii Immanuela Kanta w filozofii polskiej w poczq̨tkach XIX wieku, część 5 (s. 37-91). Toruń: Wydawnictwo Naukowe UMK.

Kwiek, M. (2006). The Classical German Idea of the University Revisited, or on the Nationalization of the Modern Institution, CPP RPS vol. 1.

Kwiek, M. (2010). Transformacje uniwersytetu. Zmiany instytucjonalne i ewolucje polityki edukacyjnej w Europie. Poznań: Wydawnictwo Naukowe UAM.

Lwoff, A. (2014). Wprowadzenie. W: J. Benda, Zdrada klerków, tłum. M. Mossakowski (s. 7-22). Warszawa: Wydawnictwo Krytyki Politycznej.

Lyotard, J.-F. (1997). Kondycja ponowoczesna, tłum. M. Kowalska i J. Migasiński. Warszawa: Aletheia.

Pokropski, M. (2013). Cielesna geneza czasu i przestrzeni. Warszawa: Wydawnictwo IFiS PAN.

Readings, B. (2017). Uniwersytet w ruinie, tłum. S. Stecko. Warszawa: Narodowe Centrum Kultury.

Schelling, F. W. J. (2016). Über einige äußere Gegensätze der Philosophie, vornehmlich den der positiven Wissenschaften. W: F. Schelling Vorlesungen über die Methode des akademischen Studiums (s. 56-63). Berlin: Hofenberg.

Sieg, U. (2005). Humboldts Erbe. Eine Einleitung. W: U. Sieg i in. (red.), Die Idee der Universität heute (s. 9-24). München: G.K. Saur.

Sobota, D. (2012). Źródła i inspiracje Heideggerowskiego pytania o bycie, t. 1. Bydgoszcz: Yakiza.

Van Loon, J. (2019). A Nomad of Academia. A Thematic Autobiography of Privilege. W: L. Donskis i in. (red.), Academia in Crisis (s. 150-168). Leiden-Boston: Brill Rodopi. Winock, M. (1984). Les intellectuels dans le siècle. Vingtième Siècle. Revue d'historien, 4, 3-14.

Żardecka, M. (2010). Wspólnoty uczonych i ich scholastyczne dyspozycje. W: M. Żardecka, P. Paczkowski (red.), Wspólnota i wspólnotowość w filozofii dawnej i współczesnej (s. 158-175). Rzeszów: Wydawnictwo UR. 